\title{
Empowering Teacher Librarians to Support STEM Education: Preliminary Findings
}

\author{
Melissa P. Johnston, PhD \\ Associate Professor \\ University of West Georgia \\ mjohnsto@westga.edu
}

\section{Introduction and Research Problem}

STEM education is grounded in problem solving, discovery, and exploratory learning, which requires students to actively engage in a situation in order to find its solution (Young, 2013). Students engage in STEM learning in many different ways, with technology and media playing an important role. Students need exposure to current and emerging technologies appropriate for STEM learning, but also instruction on how to interact with and utilize digital tools to solve problems and improve learning (Subramaniam \& Edwards, 2014; Subramaniam et al., 2013).

Teacher librarians can engage students and support teachers by providing access to digital resources, encouraging students in authentic inquiry practices, and providing real-world collaborative learning opportunities to promote STEM learning. Yet, it has been found that teacher librarians in the U.S. felt they were not prepared with the necessary knowledge, skills, and abilities to provide this support (Johnston, 2018). A federally funded project addressed this need by providing professional development (PD) for teacher librarians. This research was conducted with the purpose of identifying the influence of this PD on improving teacher librarians' knowledge, skills, and abilities to support STEM education efforts in their schools.

\section{Literature Review}

Digital resources and tools enrich student learning by enabling them to comprehend, visualize, and explain difficult concepts by providing authentic learning and analytical experiences, such as demonstrations, simulations, experiments, and observations of real world events. Teacher librarians, as information specialists, can find resources to support STEM content areas for teachers to utilize in their instruction (Rawson, Anderson, Hughes-Hassel, 2015; Subramaniam et al., 2013). The increased sense of urgency around how to effectively use digital tools and content to impact student learning, paired with teacher's continued struggles and discomfort with using digital content, positions teacher librarians to train and model for teachers how to effectively use technology for STEM learning (Anonymous, 2012; Mardis, 2014; Subramaniam et al., 2013).

Teacher librarians can teach students about utilizing a variety of digital resources, such as databases, digital video libraries, and apps, to locate information and to organize their findings through curriculum and interest based projects. As Subramaniam et al. (2012) state, the "school library program is the ideal place to connect young people, media, and technology to engage students in STEM" (p. 163). 
Yet, despite these opportunities for teacher librarians to become actively involved in STEM education, research suggests that teacher librarians are not embracing them (Johnston, 2018; Subramaniam et al, 2012; Subramaniam et al., 2013). One of the major barriers reported is the teacher librarians themselves. Previous research finds that teacher librarians do not feel confident in their content knowledge of STEM areas and therefore hesitant to collaborate with teachers (Johnston, 2018; Mardis, 2007; Rawson et al., 2015; Schultz-Jones, 2010; Subramaniam et al., 2012; Subramaniam et al., 2013; Young, 2013). Additionally, teacher librarians state they have not been adequately prepared in school library preparation programs to support and collaborate in the STEM areas, and then in practice there is a lack of professional reading and professional development opportunities in these areas (Johnston, 2018).

This deficit in the knowledge, skills, and abilities that teacher librarians need to support STEM has led to feelings of inadequacy with STEM content areas and digital tools, resulting in hesitation to work with students and teachers in these areas, therefore leading to leading to inadequate services for the STEM needs of students and teachers.

\section{Methodology}

In the summer of 2018, a federally funded project provided professional development (PD) for 38 teacher librarians on supporting STEM education, with a focus on utilizing digital tools. This PD was structured with a four day face-to-face workshop in the summer, with a semester long online course throughout the fall. The teacher librarian participants were recruited from eight states in the U.S. and work in elementary and secondary schools.

This study utilized a pre/post-test quasi-experimental design to determine the influence of the PD on teacher librarians' knowledge, skills, and abilities to support STEM education (Creswell, 2013). While pre-test results help measure a starting point or the amount of pre-existing knowledge, skills, and abilities, the post test results served to measure the learning as a result of the implementation of the of PD. The quantitative data is being analyzed using a paired t-test to evaluate the impact of the PD.

\section{Preliminary Findings \& Conclusions}

Year one of this project has just finished and post test data collection has just been completed. Therefore, data is still being analyzed, but some initial findings can be reported from the pre-test; complete findings will be reported at the 2019 IASL conference.

The majority of the teacher librarian participants (72.5\%) had not participated in STEM professional development activities, those who had mentioned conferences or workshops. The teacher librarians were questioned about the depth of their knowledge of STEM and only $17.5 \%$ felt that they had adequate knowledge of what STEM education entails. They were then asked about their knowledge of specific STEM areas - science, technology, engineering and mathematics. Over half the participants felt they had adequate knowledge of the sciences and math areas. The teacher librarians felt more knowledgeable in the area of technology, but $78 \%$ felt their knowledge was inadequate in the area of engineering content.

Teacher librarians were also asked to self-assess their knowledge of types of technologies and digital resources that are best suited for addressing STEM learning. Sixty-four percent felt they could locate digital tools to support STEM learning in the content areas, but were less knowledgeable about Open Education Resources (OER). Although a large percentage felt they could locate digital tools, when it comes to organizing and curating them, confidence decreased. Participants felt more knowledgeable using communication tools such as Skype, but less knowledgeable about using online digital tools such as videos, simulations, and data sets. And they felt the least knowledgeable about using resources such as robotics, and circuit sets. 
Teacher librarians were asked to self-assess their knowledge of effective ways to partner with teachers for teaching and integrating technology based on sound pedagogical principles, inquiry-based learning, and content knowledge. In many cases, they were unsure of themselves. It was interesting to note that less than $20 \%$ of the teacher librarians thought they had adequate knowledge to collaborate with teachers in the STEM area and less than $40 \%$ felt they had adequate knowledge about appropriate strategies for the infusion of technology in the STEM content areas to support learning. Participants felt least confident in their knowledge about design thinking/engineering design process and most confident in their knowledge of maker spaces and maker education.

\section{Implications}

Examination of the pre-test data confirms previous, there is a significant gap in the knowledge, skills, and abilities of teacher librarians when it comes to supporting STEM education efforts in their schools. Additionally, teacher librarians aren't being offered many professional growth opportunities to further their knowledge in this area. One implication from this research is the development of the PD modules to address this need for targeted PD for teacher librarians. The modules developed for the workshop focused on addressing: Learning About the STEM Content Areas and Standards; Digital Resources and Open Educational Resources (OER) for the STEM areas; The Role of the School Librarian in Supporting STEM Education, which focuses on collaborating with STEM area teachers, integrating digital tools, and selecting and curating digital resources; and Making Connections for STEM, which included connecting with local community resources, how to look for funding opportunities, and grant writing. Once these modules have gone through another year of pilot testing, they will be made freely accessible.

The other major implication is for teacher librarian preparation programs. Programs must evolve to address the needs of today's teacher librarians, which includes working with all content areas, not just research and reading. The areas of strengths, weaknesses, and the gaps identified by participants can lead to changes in the curriculum provided to pre-service teacher librarians.

\section{References}

Creswell, J. W. (2013). Research design: Qualitative, quantitative, and mixed methods approaches (4th ed.).Thousand Oaks, CA: Sage.

Johnston, M. P. (2018). Supporting STEM education: Needs assessment of southeastern rural teacher librarians. School Libraries Worldwide, 24(2), 62-79.

Mardis, M. A. (2007). School libraries and science achievement: A view from Michigan's middle schools. School Library Media Research, 10. Retrieved from www.ala.org/aasl/slr

Mardis, M. A. (2014). Ready for STEM? A leading commercial multimedia database as a source for media-rich science, technology, engineering, and mathematics assets K-12 library collections. Library Resources \& Technical Services, 58(4), 250-264.

Rawson, C., Anderson, J., \& Hughes-Hassel, S. (2015). Preparing pre-service school librarians for science-focused collaboration with pre-service elementary teachers: The design and impact of a cross-class assignment. School Library Research, 18. Retrieved from http://www.ala.org/aasl/slr/

Schultz-Jones, B. (2010). School librarians, teachers, and optimal STEM learning environments. Knowledge Quest, 39(2), 12-18.

Subramaniam, M., Ahn, J., Fleischmann, K. R., \& Druin, A. (2012). Reimagining the role of school libraries in STEM education: Creating hybrid spaces for exploration. Library Quarterly, $82(2), 161-182$.

Subramaniam, M., Ahn, J., Waugh, A., Taylor, N. G., Druin, A., Fleischmann, K. R., \& Walsh, G. (2013). The role of school librarians in enhancing science learning.Journal of Librarianship and Information Science, 47(1), 1-14. 
Subramaniam, M., \& Edwards, A. R. (2014). The collaboration conundrum between school librarians and mathematics teachers. International Journal of Libraries and Information Services (LIBRI), 64(2), 185-209.

Young, T. E. (2013). 24/7 STEMulation: Reinventing discovery.Library Media Connection, 31(6), $20-22$.

\section{Biography}

Melissa P. Johnston is an Associate Professor at the University of West Georgia, where she teaches graduate courses in the school library certification program. Her research focuses on the school librarian's leadership role in integrating technology. 